Nevşehir Bilim ve Teknoloji Dergisi Cilt 6(ICOCEE 2017 Özel Sayı) 314-325 2017

DOI: 10.17100/nevbiltek.322416

URL: http://dx.doi.org/10.17100/nevbiltek.322416

\title{
Ultrasonic Pulse Velocity and Compressive Strength Evaluation of Concrete
}

\section{Containing Fly Ash Exposed to High Temperatures}

\author{
Şakir ERDOĞDU*, Ufuk KANDİL, Memduh NAS, Şirin KURBETCİ, Safa NAYIR \\ Karadeniz Teknik Üniversitesi, Mühendislik Fakültesi, İnşaat Mühendisliği Bölümü, Trabzon
}

\begin{abstract}
Concrete is frequently subjected to various adverse environmental effects throughout its service life such as fire and high temperature. Although the resistance of concrete against fire is superior to many other construction materials up to a certain temperature, its performance starts to decrease at temperatures above $400^{\circ} \mathrm{C}$. Serious physical and mechanical damage starts to take place particularly above $400^{\circ} \mathrm{C}$ and the performance of concrete decreases due to such impacts.

Fly ash is an artificial pozzolanic material that can be used as a mineral additive in making concrete. Fly ash has on the one hand a beneficial effect on the performance of the concrete and allows economy by saving cement on the other hand as it is a waste product of thermal power plants.

In this study, the compressive strength and ultrasonic pulse velocities of concrete containing fly ash subjected to high temperatures was investigated. The measurements were taken at the end of 28 days of standard curing and 28 days of standard curing plus 90 days of air curing in a laboratory condition. Concretes of $300 \mathrm{~kg} / \mathrm{m}^{3}$ were produced and fly ash was replaced with cement at ratios of $20 \%, 30 \%$ and $40 \%$ by weight of cement. The ultrasonic and compressive strengths measurements were taken on $100 \mathrm{~mm}$ cubes. The temperatures applied to concrete were $200^{\circ} \mathrm{C}, 400^{\circ} \mathrm{C}, 600^{\circ} \mathrm{C}$, and $800^{\circ} \mathrm{C}$, respectively.

It has been found that fly ash substitution does not have a beneficial effect on concrete subjected to high temperature both in ultrasonic pulse velocity and compressive strength.
\end{abstract}

Keywords: High temperature, fly ash, ultrasonic pulse velocity, compressive strength.

\section{Yüksek Sıcaklığa Maruz Uçucu Kül İçeren Betonun Ultrases Geçiş Hızı ve Basınç Dayanımının Değerlendirilmesi}

$\ddot{O} \mathbf{z}$

Beton servis ömrü boyunca yangın ve yüksek sıcaklık ve benzeri çeşitli olumsuz çevresel etkilere maruz kalır. Betonun yangına karşı direnci belirli bir sıcaklığa kadar diğer birçok yapı malzemesinden daha üstündür. $400^{\circ} \mathrm{C}$ `nin üzerindeki sıcaklıklarda ciddi fiziksel ve mekanik hasarlar oluşmaya başlar ve bu etkiler nedeniyle betonun performansı düşer.

Uçucu kül beton üretiminde mineral katkı olarak kullanılan yapay puzolanik bir malzemedir. Uçucu kül kullanımı betonun performansı üzerinde olumlu bir etki oluştururken termik santrallerin atık bir ürünü olduğu için betonda kullanılması ekonomik ve çevrecidir.

Bu çalışmada, yüksek sıcaklığa maruz kalmış uçucu kül içeren betonun basınç dayanımı ve ultrases geçiş hızı araştırılmıştır. Ölçümler 28 gün standart kür ve 28 gün standart kür ve ardından 90 gün laboratuvar ortamında kür edilmesi sonunda gerçekleştirilmiştir. Betonlar $300 \mathrm{~kg} / \mathrm{m}^{3}$ bağlayıcı dozajında ve uçucu kül çimento ile ağırlıkça $\% 20, \% 30$ ve $\% 40$ oranlarında ikame edilerek üretilmiştir. Ultrases ve basınç dayanımı deneyleri $100 \mathrm{~mm}$ küp numuneler üzerinde gerçekleştirilmiştir. Uygulanan sicaklıklar sirasiyla $200^{\circ} \mathrm{C}, 400^{\circ} \mathrm{C}, 600^{\circ} \mathrm{C}$ ve $800^{\circ} \mathrm{C}^{\prime}$ dir.

Uçucu kül ikamesinin yüksek sıcaklığa maruz betonun hem ultrases geçiş hızı hem de basınç dayanımına olumlu bir etki sağlamadığı görülmüştür.

Anahtar Kelimeler: Yüksek sıcaklık, uçucu kül, ultrases geçiş hızı, basınç dayanımı.

*e-mail: shake@ktu.edu.tr 


\section{Introduction}

Concrete is a building material that performs very well under the influence of fire as it is generally behaves to other external effects. In this sense, concrete can sustain its fire-related performance for a relatively long time [1]. Some physical and chemical changes occur during the fire when the temperature is above a certain level [2]. The reasons for this are the changes in the physical properties of the cement paste and the aggregate [3-6].

The thermal properties of concrete are related to thermal conductivity, thermal expansion, thermal diffusion coefficients and specific heat values. Resistance to high temperatures of concrete is closely related to its main constituent aggregates and its mineral composition [7].

Water in the cement paste can be found as hydrated water in the cement gel, in the gel pores, and as free water in the capillary gaps. Free water in the capillary gaps evaporates when the temperature of concrete exceeds $110^{\circ} \mathrm{C}$ [8 and 9]. When the temperature reaches $300^{\circ} \mathrm{C}$, the thermal expansion in the aggregate causes internal tension of concrete to increase. In case the temperature exceeds $300^{\circ} \mathrm{C}$, the separation of the non-evaporating chemically bound water under normal conditions increases the damage level of concrete [3]. In case the temperature reaches $400^{\circ} \mathrm{C}$, the calcium hydroxide in the cement paste breaks into calcium oxide and water. This leads to a volume reduction of approximately $33 \%$ [6, 10 and 11]. When the temperature reaches $600^{\circ} \mathrm{C}$, the hydration product calcium-silicate-hydrate, which is responsible for the strength of the cement, is destroyed. Besides this, the cement paste shrinks and a significant decrease in strength occurs $[6,10-12]$. When the temperature reaches $800^{\circ} \mathrm{C}$, it's about to breakdown of the concrete completely and further the concrete is going to be disintegrated [5, 13 and 14].

Depending on the increasing temperature, the change in the mechanical properties of concrete is related to many parameters. Some of these parameters are the physical and chemical properties of the materials, and the type and the amounts of additives used [15].

The purpose of this study is to investigate the changes in the compressive strength and the ultrasonic pulse velocity of concretes containing fly ash at high temperatures. Measurements were taken at the end of 28 days of standard curing and 28 days of standard curing plus 90 days of air curing in a laboratory condition.

\section{Material and Methods \\ Materials}

Calcareous crushed aggregate with a maximum grain size of $16 \mathrm{~mm}$ and crushed sand were used in the study. The particle density at SSD state, water absorption and the moisture content of the aggregates are given in Table 1. The gradation of the aggregate mixture along with the reference curves is given in Figure 1.

Table 1. Particle density, water absorption, and moisture content of aggregates

\begin{tabular}{cccc}
\hline \multicolumn{4}{c}{ Table 1. Particle density, water absorption, and moisture content of aggregates } \\
\hline $\begin{array}{c}\text { Aggregate } \\
\text { (Crushed stone) }\end{array}$ & Particle density, $\mathrm{Mg} / \mathrm{m}^{3}$ & Water absorption, $\%$ & Moisture content, \% \\
Crushed sand & 2.74 & 1.00 & 0.15 \\
\hline
\end{tabular}




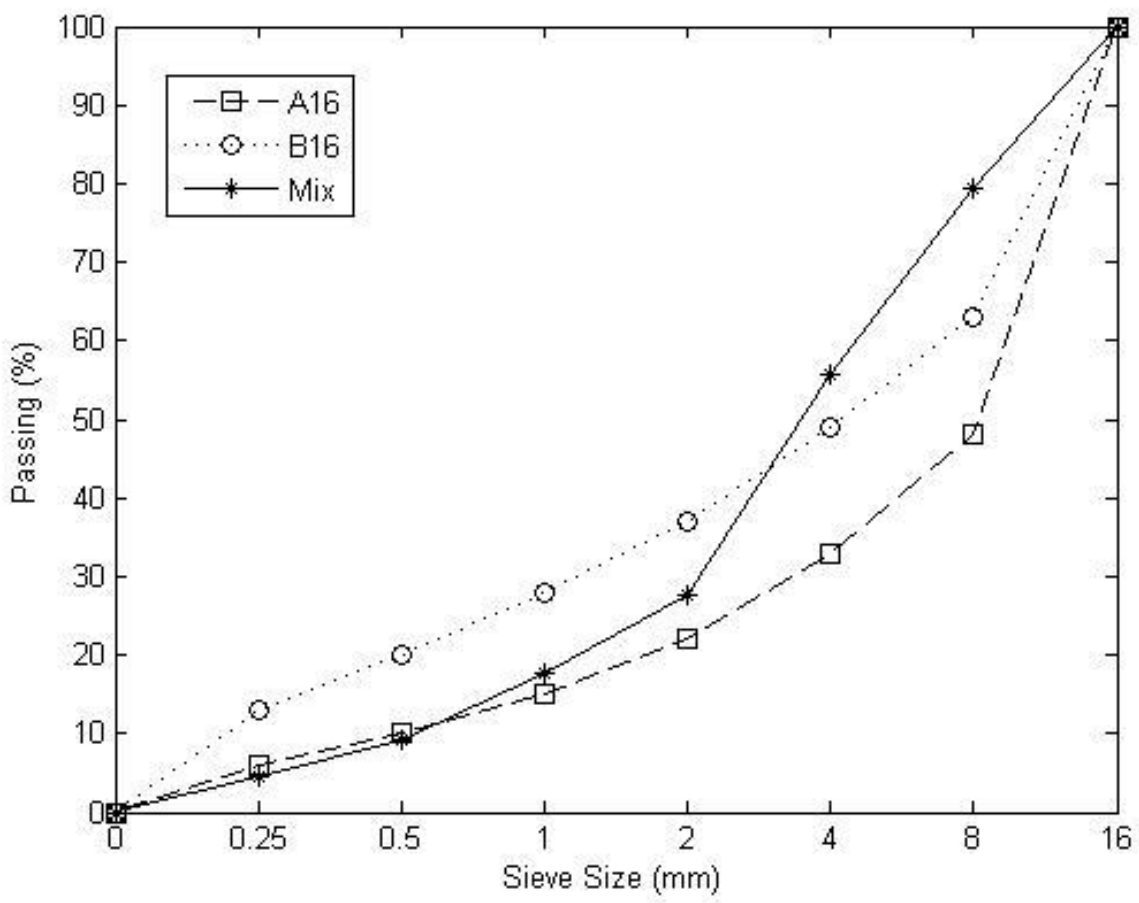

Figure 1. The gradation of the aggregate mix and the reference curves

The cement used in the study was CEM I 42.5 R type, manufactured by Aşkale Trabzon Cement Factory. Some properties of the cement used are given in Table 2.

Table 2. Chemical composition, physical and mechanical properties of cement

\begin{tabular}{|c|c|c|c|c|}
\hline \multicolumn{2}{|c|}{ Chemical Composition } & \multicolumn{3}{|c|}{ Physical and Mechanical Properties } \\
\hline Oxides & Content, \% & Retained on $45 \mu \mathrm{m}$ sieve, $\%$ & & 9.8 \\
\hline $\mathrm{SiO}_{2}$ & 19.46 & Retained on $90 \mu \mathrm{m}$ sieve, $\%$ & & 1.0 \\
\hline $\mathrm{Al}_{2} \mathrm{O}_{3}$ & 5.11 & Specific surface (Blaine), $\mathrm{m}^{2} / \mathrm{kg}$ & & 412.6 \\
\hline $\mathrm{Fe}_{2} \mathrm{O}_{3}$ & 3.31 & Particle density, $\mathrm{Mg} / \mathrm{m}^{3}$ & & 3.12 \\
\hline $\mathrm{CaO}$ & 60.23 & \multirow{2}{*}{ Setting times (Vicat), min. } & Initial & 140 \\
\hline $\mathrm{MgO}$ & 2.08 & & Final & 200 \\
\hline $\mathrm{SO}_{3}$ & 3.05 & Water demand, $\%$ & & 29.2 \\
\hline $\mathrm{Na}_{2} \mathrm{O}$ & 0.27 & Soundness, mm & & 1.0 \\
\hline $\mathrm{K}_{2} \mathrm{O}$ & 0.69 & & 2-day & 28.0 \\
\hline $\mathrm{Cl}^{-}$ & 0.02 & Compressive strength, $\mathrm{MPa}$ & 7-day & 40.4 \\
\hline Loss on ignition & 3.00 & & 28-day & 51.5 \\
\hline
\end{tabular}

The fly ash was obtained from Zonguldak-Çatalağzı power generation plant. The chemical composition of the fly ash is given in Table 3. A superplasticizer type chemical admixture was also used in the production of the mixes. 


\begin{tabular}{cc} 
Table 3. Chemical composition of fly ash \\
\hline Density $\left(\mathrm{g} / \mathrm{cm}^{3}\right)$ & 2.34 \\
$\mathrm{SiO}_{2}(\%)$ & 61.57 \\
$\mathrm{Al}_{2} \mathrm{O}_{3}(\%)$ & 20.25 \\
$\mathrm{Fe}_{2} \mathrm{O}_{3}(\%)$ & 7.30 \\
$\mathrm{CaO}(\%)$ & 1.54 \\
\hline
\end{tabular}

\section{Mixture proportions}

The mix proportions of the concretes are given in Table 4. The amount of binder and the water to cement ratio were kept constant as $300 \mathrm{~kg} / \mathrm{m}^{3}$ and 0.60 for all mixes, respectively. Thirty $100 \mathrm{~mm}$ cube specimens were produced for each batch. All specimens were demolded 24 hours after the production is performed.

Table 4. Mix proportions of the concretes produced

\begin{tabular}{cccccc}
\hline & & \multicolumn{3}{c}{ Amount of constituent materials, $\mathrm{kg} / \mathrm{m}^{3}$} \\
$\begin{array}{c}\text { Designation } \\
\text { of the mixes }\end{array}$ & $\begin{array}{c}\text { Replacement ratio for } \\
\text { the fly ash, } \%\end{array}$ & Cement & Water & Aggregate & Fly ash \\
300PC & 0 & 300 & 1885 & 0 \\
300FA20 & 20 & 240 & 180 & 1879 & 60 \\
300FA30 & 30 & 210 & & 1876 & 90 \\
300FA40 & 40 & 180 & & 1874 & 120 \\
\hline
\end{tabular}

Thirty $100 \mathrm{~mm}$ cube specimens were prepared for each batch. All specimens were placed in standard curing condition for 28 days. Then fifteen specimens were subjected to ultrasonic pulse velocity and the compressive strength tests. The rest 15 specimens were placed in a laboratory condition for additional 90 days of air curing and then ultrasonic pulse velocity and the compressive strength tests were performed. Thus, the tests were performed for two different curing conditions. At the end of each curing condition, three specimens from each casting were subjected to ultrasonic pulse velocity and compressive strength tests after the exposure to high temperature at $200^{\circ} \mathrm{C}, 400^{\circ} \mathrm{C}, 600^{\circ} \mathrm{C}$, and $800^{\circ} \mathrm{C}$. Furthermore, three specimens from each casting and each curing condition were subjected to testing without subjection to high temperatures.

The oven used for the high temperature exposure and the samples exposed to high temperature are shown in Figure 2. 
Erdoğdu Ş., Kandil U., Nas M., Kurbetci Ş., Nayır S.

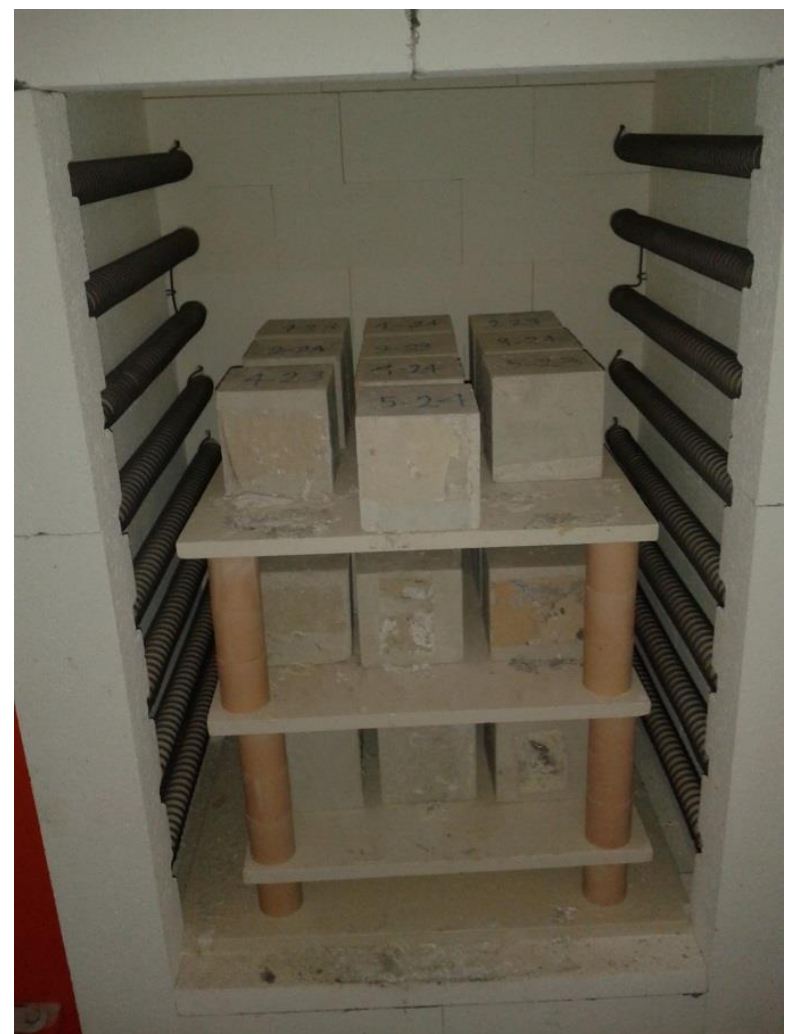

Figure 2. The oven used for the high temperature exposure and the specimens

The ultrasonic pulse velocity test setup is shown in Figure 3. In the test, the transit time of ultrasonic sound through the specimen was measured. A gel was used on the faces of the specimen to provide high conductivity. The average duration of the transit time was taken as the average of the measurements of both sides of the specimen. Subsequently, the ultrasonic pulse velocity was calculated by dividing the specimen length by the measured transit time. Measurement of ultrasonic pulse transition times were not possible due to high level of damage occurred at $800^{\circ} \mathrm{C}$.

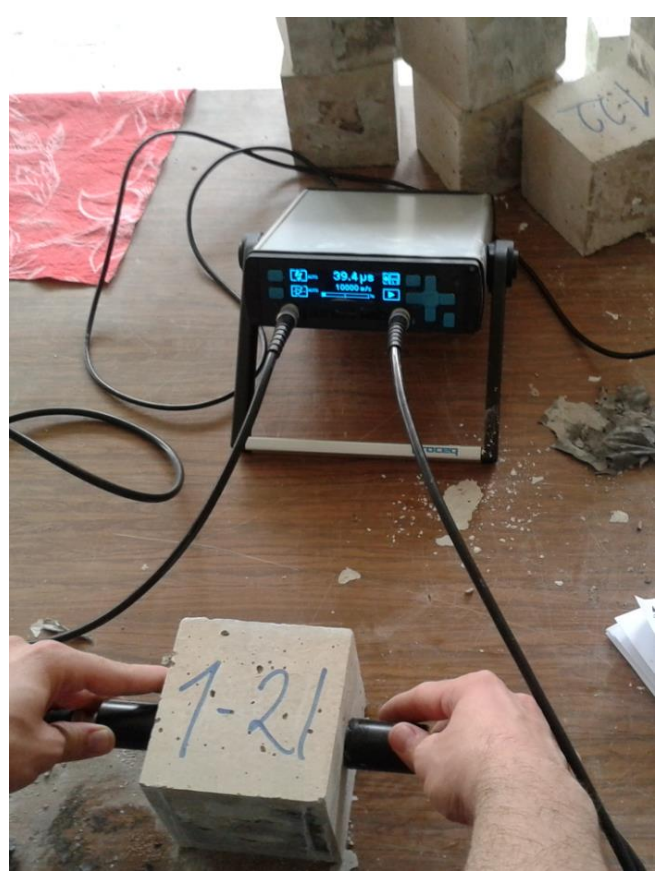

Figure 3. Ultrasonic pulse velocity test set up 
Nevşehir Bilim ve Teknoloji Dergisi Cilt 6(ICOCEE 2017 Özel Sayı) 314-325 2017

Table 5. Pulse velocity ratings for concrete quality grading [16]

Pulse Velocity $(\mathrm{km} / \mathrm{s})$

Quality Grade of Concrete

$>4.5$

Excellent

$3.5-4.5$

Good

$3-3.5$

Medium

$<3.0$

Poor

Compressive strengths were determined on $100 \mathrm{~mm}$ cube specimens as seen in Figure 4. The compressive strength test was performed according to TS EN 12390-3 [17].

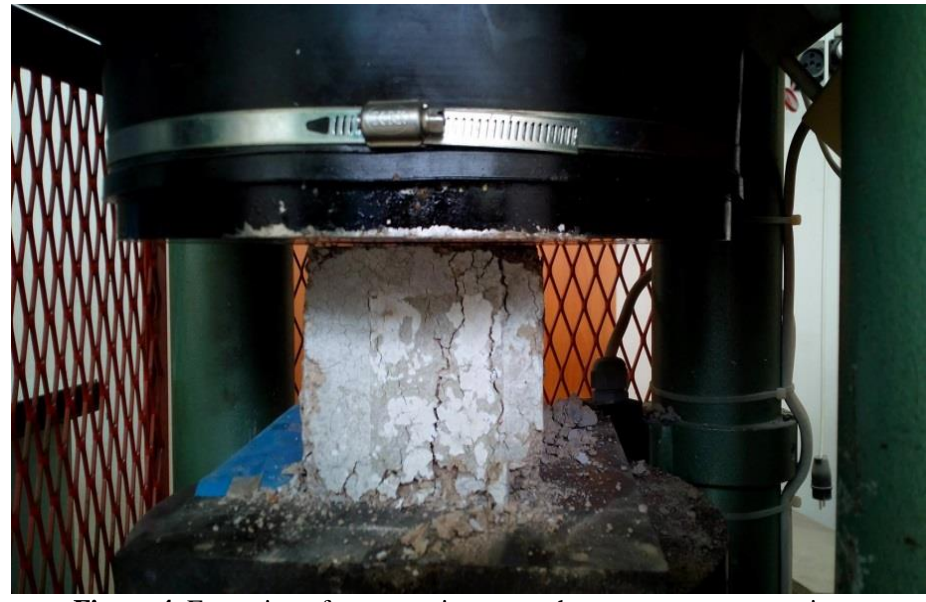

Figure 4. Execution of compressive strength test on concrete specimen

\section{Results and Discussion}

Ultrasonic pulse velocity

Figure 5 and Figure 6 show the ultrasonic pulse velocity measurements for concretes containing fly ash at replacement ratios of $\% 0, \% 20, \% 30, \% 40$ and concrete exposed to a laboratory condition at $25^{\circ} \mathrm{C}$ and at high temperatures following 28 days of standard curing.

Figure 5 indicates that the ultrasonic pulse velocity of concretes decreases as the replacement ratio of fly ash increases. This is valid for all exposure temperatures. The decrease is quite significant more obvious for concretes subjected to $400^{\circ} \mathrm{C}$ and $600^{\circ} \mathrm{C}$. Similarly, as can be seen from Figure 6, the ultrasonic pulse velocity of concretes decreases as the temperature increases. Considering both graphs, it can be concluded that incorporation of fly ash in concrete adversely affects the concrete in relation with its ultrasonic pulse velocity. 
Erdoğdu Ş., Kandil U., Nas M., Kurbetci Ş., Nayır S.

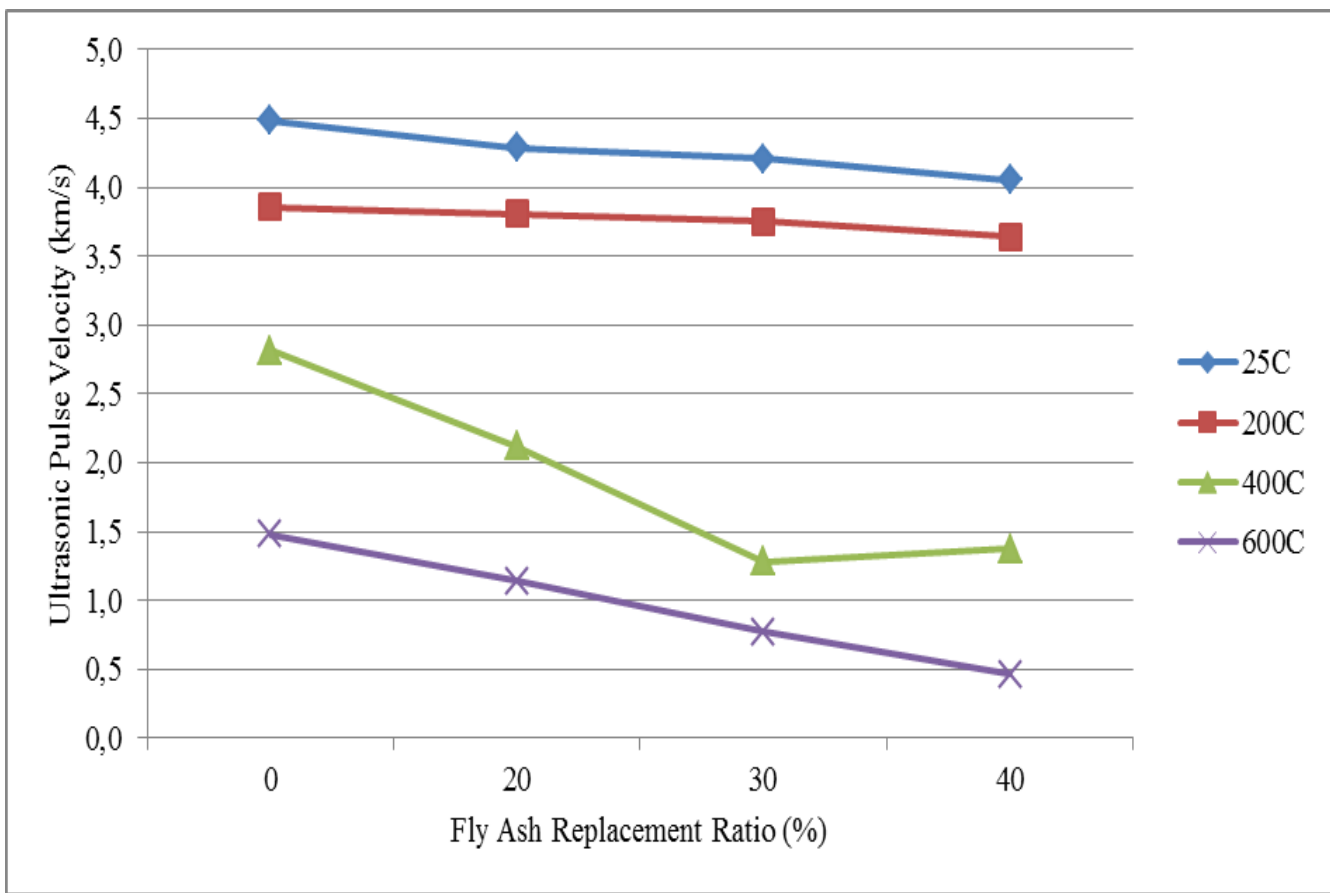

Figure 5. Relation between ultrasonic pulse velocity versus fly ash replacement obtained at the end of 28 days of standard curing

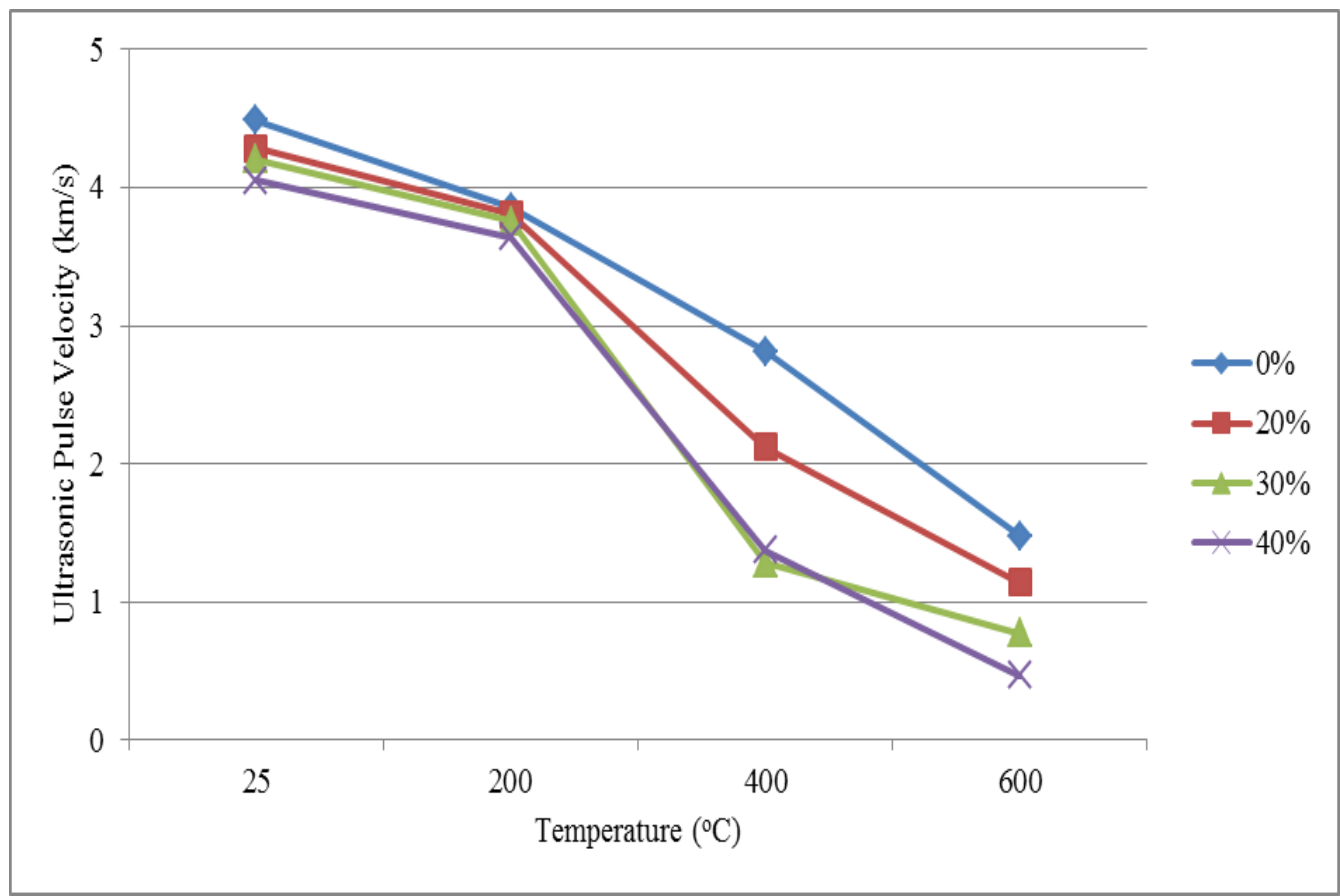

Figure 6. Relation between ultrasonic pulse velocity versus temperature obtained at the end of 28 days of standard curing

Figure 7 and Figure 8 show the ultrasonic pulse velocity of concretes containing fly ash measured following 28 days of standard curing plus 90 days of air curing in a laboratory condition. As can be seen from both figures, the use of fly ash in concrete adversely affects the ultrasonic pulse velocity of concretes in such a curing condition. However, longer curing seems to be beneficial on concretes exposed to $400^{\circ} \mathrm{C}$ and $600^{\circ} \mathrm{C}$ concerning to ultrasonic pulse velocity. In another word, prolonging the curing time obviously increases the ultrasonic pulse velocity of concrete. 
Nevşehir Bilim ve Teknoloji Dergisi Cilt 6(ICOCEE 2017 Özel Sayı) 314-325 2017

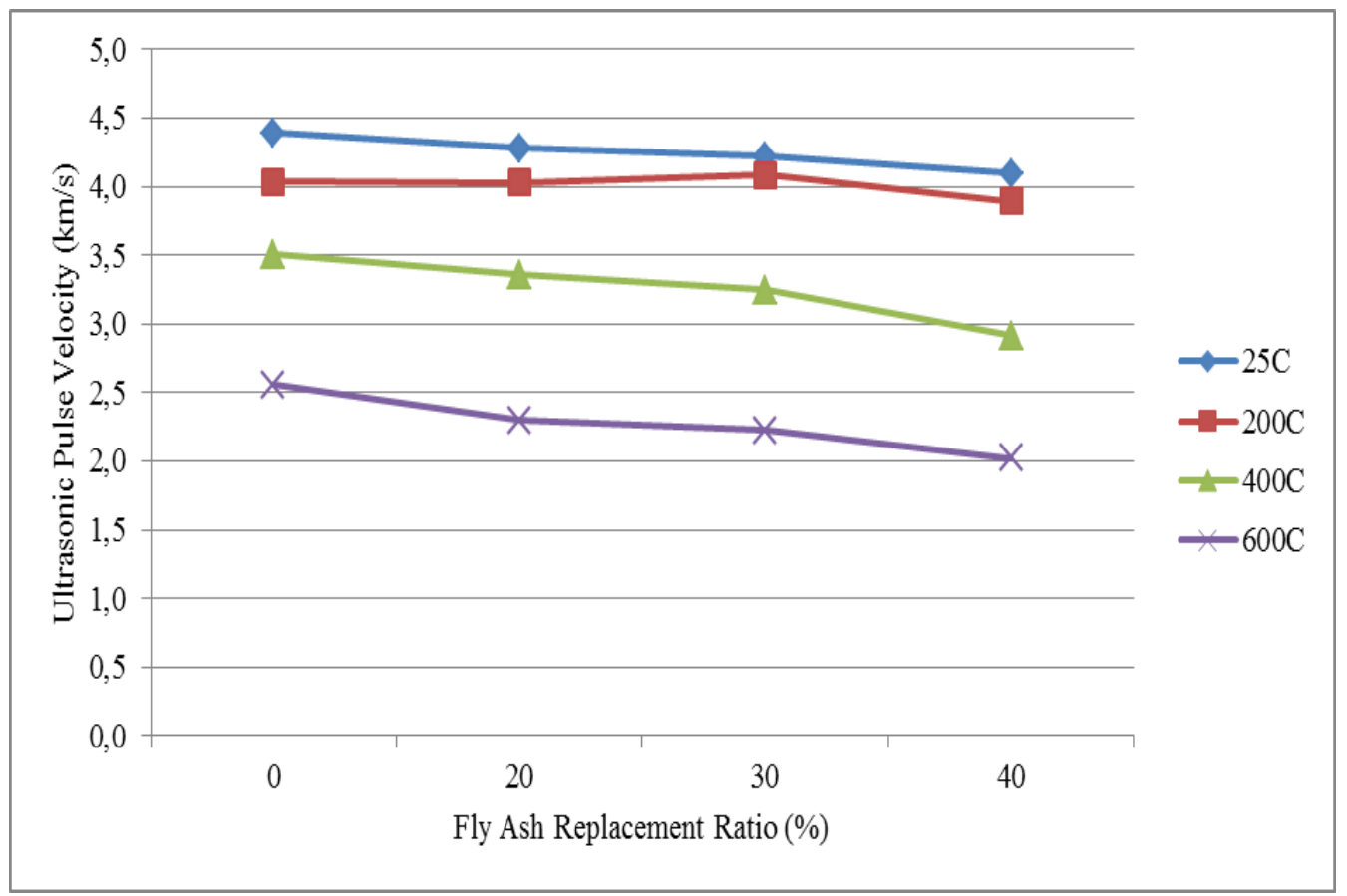

Figure 7. Relation between ultrasonic pulse velocity versus fly ash replacement obtained at the end of 28 days of standard curing plus 90 days of air curing in laboratory condition

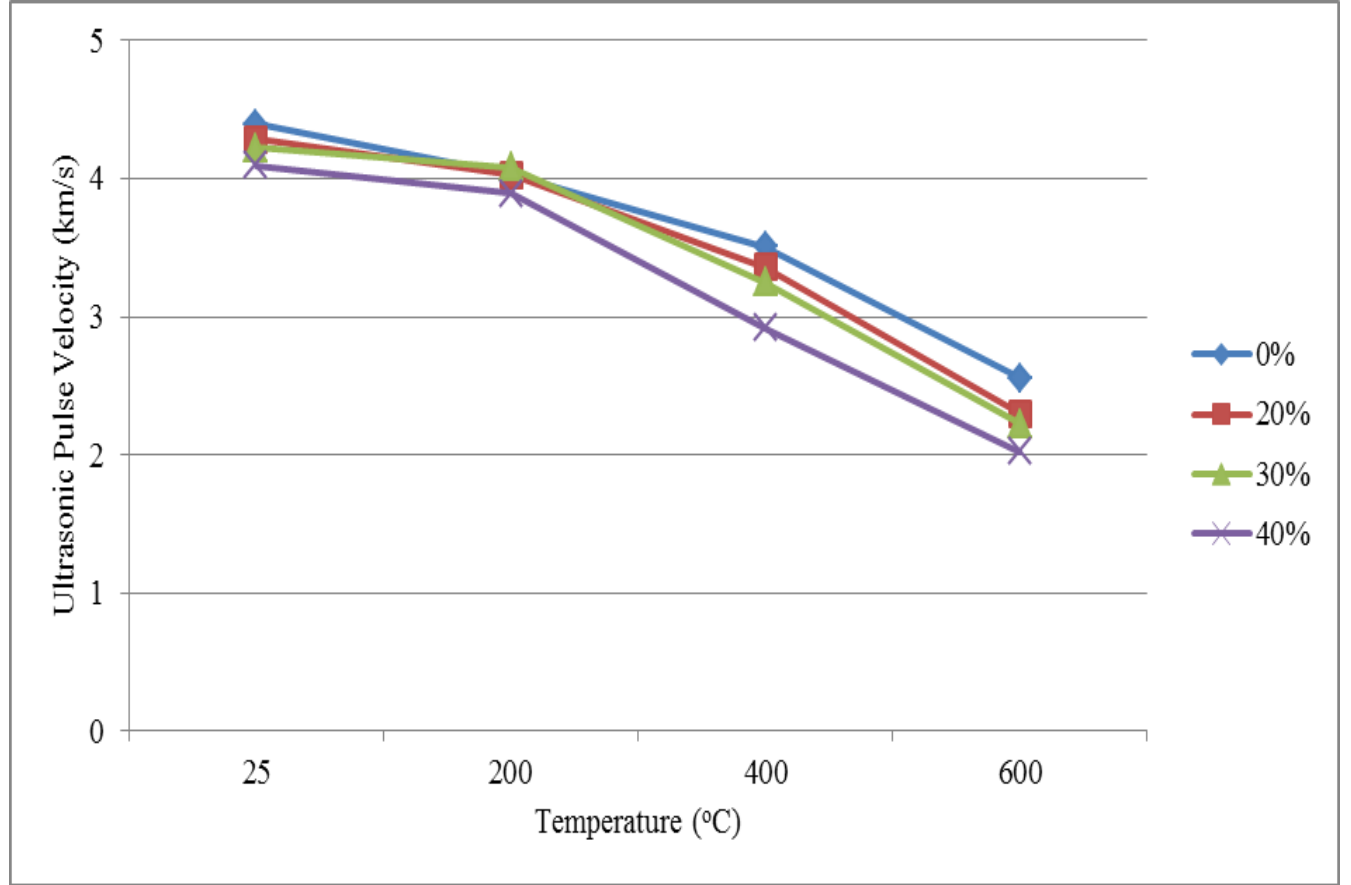

Figure 8. Relation between ultrasonic pulse velocity versus temperature obtained at the end of 28 days of standard curing plus 90 days of air curing in laboratory condition

In a study performed [18], it has been stated out that ultrasonic pulse velocity of concrete decreases as the incorporation of fly ash increases. This result is quite similar to the results obtained in the present study.

\section{Compressive Strength}

Figure 5 and Figure 6 show the compressive strengths of concretes containing fly ash at replacement ratios of $\% 0, \% 20, \% 30, \% 40$ and concrete exposed to a laboratory condition at $25^{\circ} \mathrm{C}$ and at high temperatures following 28 days of standard curing. When Figure 9 is closely examined, the 
compressive strength decreases as the replacement ratio fly ash increases for all exposure temperatures. Figure 10 indicates that the compressive strengths of concretes subjected to $200^{\circ} \mathrm{C}$ and $400^{\circ} \mathrm{C}$ are higher than the strength of concrete at $25^{\circ} \mathrm{C}$. The reasons for this may be attributed to the beneficial effect of temperatures up to $400^{\circ} \mathrm{C}$ on hydration process of concrete. On the contrary, temperatures above $400^{\circ} \mathrm{C}$ have an adverse effect on the compressive strength of concrete as concrete decomposes internally at such temperatures.

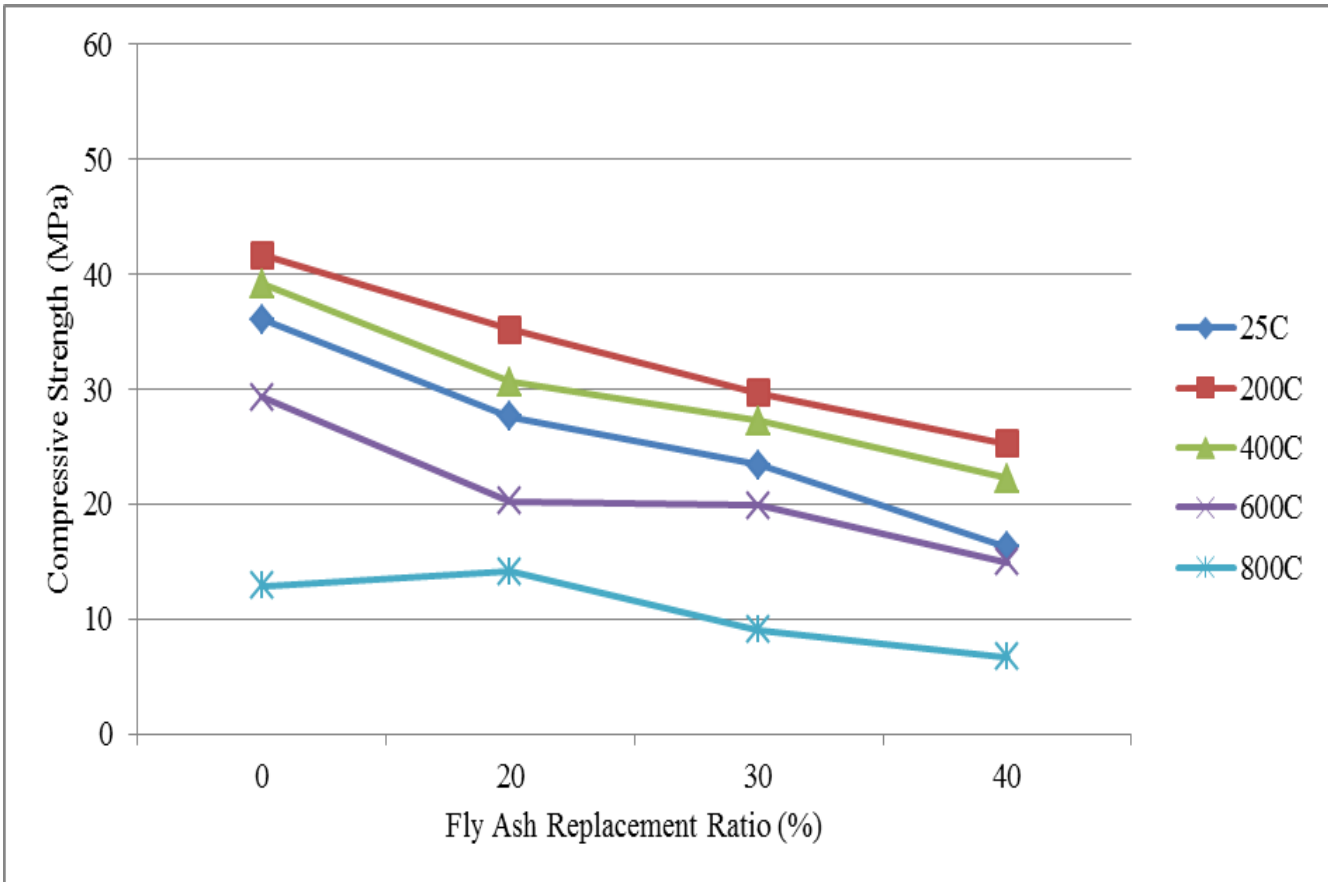

Figure 9. Relation between compressive strength versus fly ash replacement obtained at the end of 28 days of standard curing

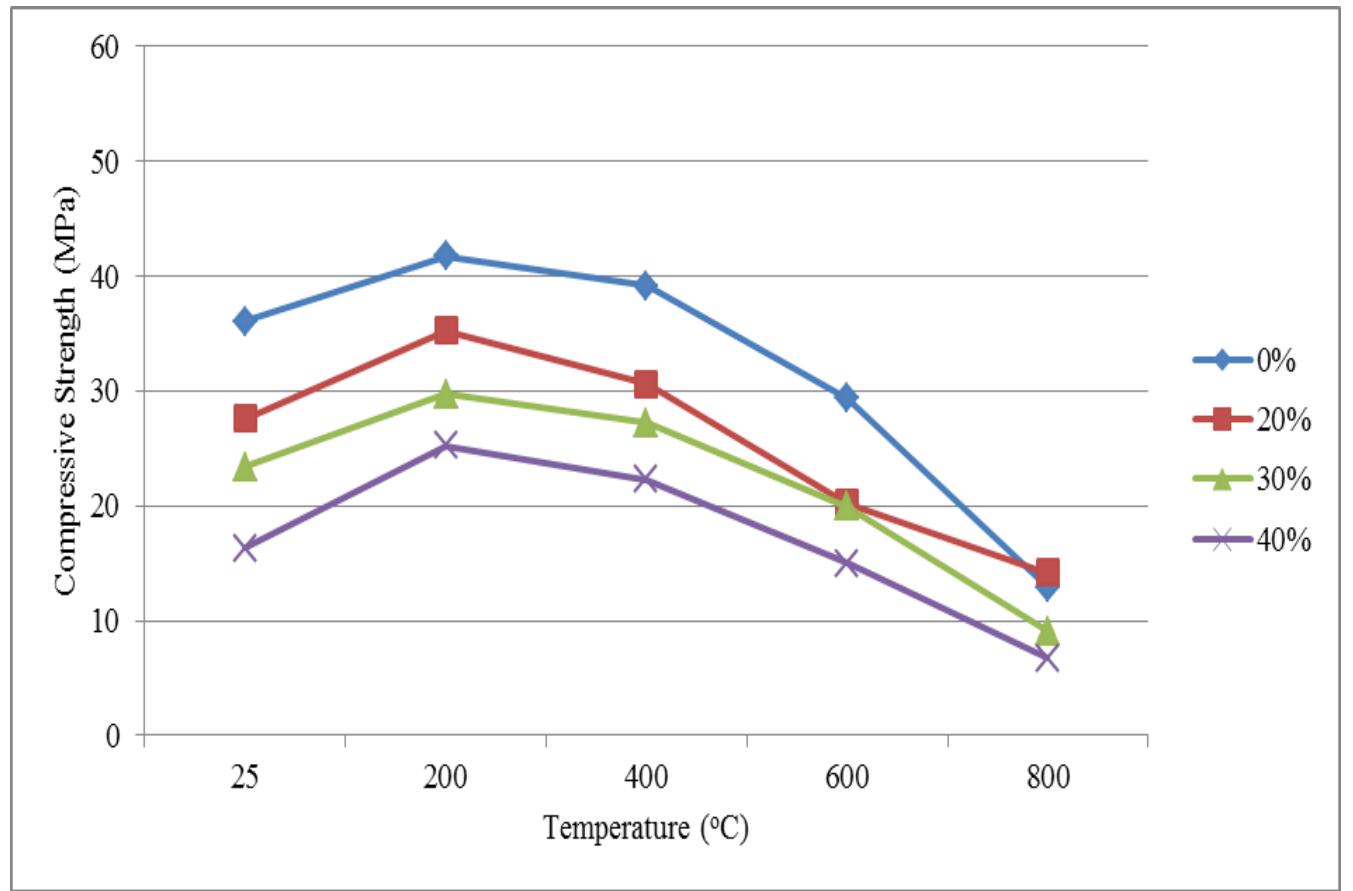

Figure 10. Relation between compressive strength versus temperature obtained at the end of 28 days of standard curing 
Figure 11 and Figure 12 show the compressive strengths of concretes containing fly ash measured following 28 days of standard curing plus 90 days of air curing in a laboratory condition. Figure 11 clearly indicates that the compressive strength of concrete decreases as the replacement ratio of fly ash increases. The compressive strengths of concretes subjected to high temperatures is lower compared to the compressive strength of concrete at $25^{\circ} \mathrm{C}$ for all replacement ratios of fly ash. This behavior is rather different from that of observed in Figure 10. This may be attributed to the beneficial effect of longer curing time on the hydration process of concrete since the hydration process.

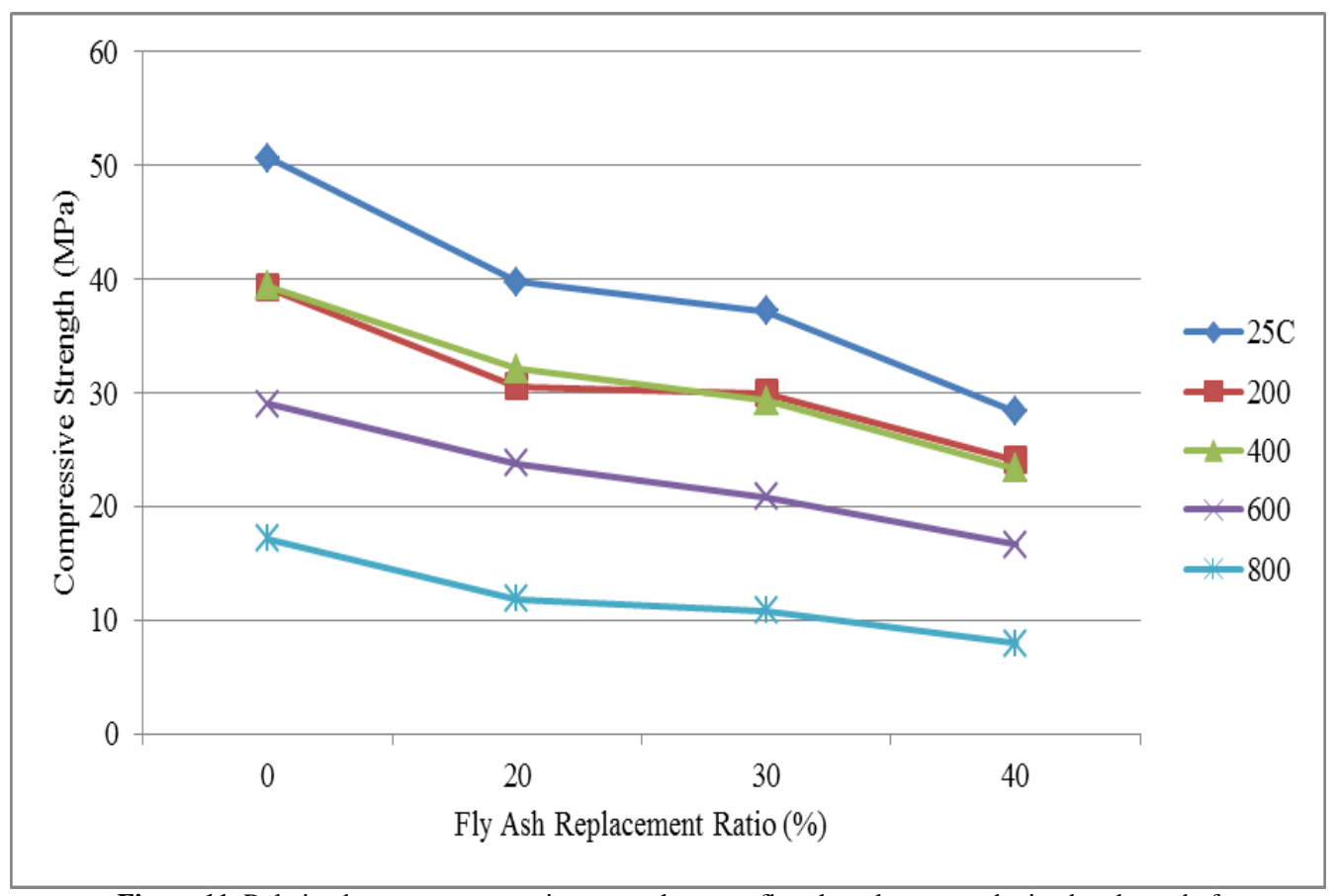

Figure 11. Relation between compressive strength versus fly ash replacement obtained at the end of 28 days of standard curing plus 90 days of air curing in laboratory condition

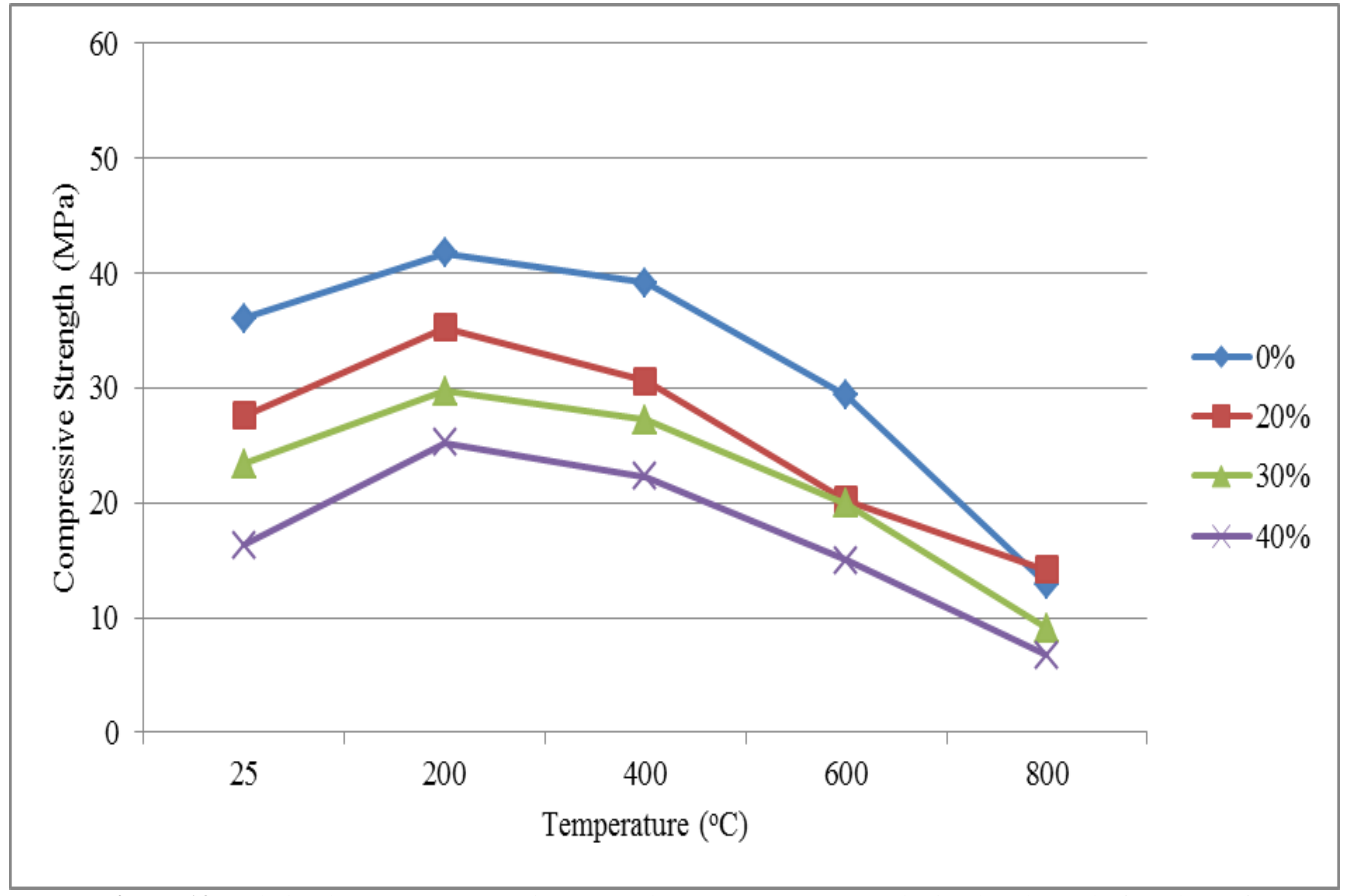

Figure 12. Relation between compressive strength versus temperature obtained at the end of 28 days of standard curing plus 90 days of air curing in laboratory condition 
In a study carried out [18], it was stated that the compressive strength of concrete decreases as the fly ash replacement ratio increases that this result is quite parallel to the results obtained from the present study.

\section{Conclusions}

Based on the experimental study performed on the effects of high temperature on the ultrasonic pulse velocity and compressive strength of concrete containing fly ash, the following main conclusions may be drawn:

-The use of fly ash in concrete has an adverse effect on the ultrasonic pulse velocity and the compressive strength of concrete subjected to high temperatures.

-Exposure temperatures above $600^{\circ} \mathrm{C}$ is highly destructive, particularly for concretes with a fly ash replacement ratio of $\% 40$.

-If the targeted strength is achieved, using fly ash in concrete exposed to temperatures below $400^{\circ} \mathrm{C}$ can be considered economically beneficial.

\section{References}

[1] Neville A.M., "Properties of Concrete” John Wiley\&Sons, New York, 1997

[2] Hertz K.D., "Concrete strength for fire safety design" Magazine of Concrete Research, 57, 445453,2005

[3] Khoury G.A., Majorana C.E., Pesavento F., Schrefler B.A., "Modelling of heated concrete", Magazine of Concrete Research, 54, 77-101, 2002

[4] Georgali B., Tsakiridis P.E., "Microstructure of fire-damaged concrete", Cement and Concrete Composites, 27, 255-259, 2005

[5] Demirel B., Kelestemur O., "Effect of elevated temperature on the mechanical properties of concrete produced with finely ground pumice and silica fume" Fire Safety Journal, 45, 385391,2010

[6] Arioz O., "Effects of elevated temperatures on properties of concrete" Fire Safety Journal, 42, 516-522, 2007

[7] Baradan B., Yazıcı H., Ün H., "Beton ve betonarme yapılarda kalıcılık (durabilite)", Türkiye Hazır Beton Birliği, İstanbul, 2010

[8] Feldman R.F., Ramachandran V.S., "Differentiation of interlayer and adsorbed water in hydrated portland cement on thermal analysis" Cement and Concrete Research, 1, 607-620, 1971

[9] Khoury G.A., Majorana C.E, Pesavento F, Schrefler B.A., "Modelling of heated concrete" Magazine of Concrete Research, 54, 77-101, 2002

[10] Zega C.J., Di Maio A.A., "Recycled concrete exposed to high temperatures" Magazine of Concrete Research, 58, 675-682, 2006

[11] Yuzer N., Akoz F., Öztürk L.D., "Compressive strength-color change relation in mortars at high temperature” Cement and Concrete Research, 34, 1803-1807, 2004 
[12] Georgali B., Tsakiridis P.E., "Microstructure of fire-damaged concrete" Cement and Concrete Composites, 27, 255-259, 2005

[13] Vydra V., Vodak F., Kapickova O., Hoskova S., "Effect of temperature on porosity of concrete for nuclear-safety structures" Cement and Concrete Research, 31, 1023-1026, 2001

[14] Masse S., Vetter G., Boch P., Haehnel C., "Elastic modulus changes in cementitious materials submitted to thermal treatments up to $1000^{\circ} \mathrm{C}$ " Advances in Cement Research, 14, 169-177, 2002

[15] Ergün A., Kürklü G., Başpınar M.S., Mansour M.Y., "The effect of cement dosage on mechanical properties of concrete exposed to high temperatures" Fire Safety Journal, 55, 160167,2013

[16] IS 13311 Part I Standard code of practice for non-destructive testing of concrete: part 1ultrasonic pulse velocity bureau of Indian standards, New Delhi, 1992

[17] TS EN 12390-3 Testing hardened concrete-part 3: compressive strength of test specimens, Ankara, 2010

[18] Rao S.K., Sravana P., Rao T.C., "Experimental studies in ultrasonic pulse velocity of roller compacted concrete pavement containing fly ash and m-sand" International Journal of Pavement Research and Technology, 9, 289-301, 2016 